
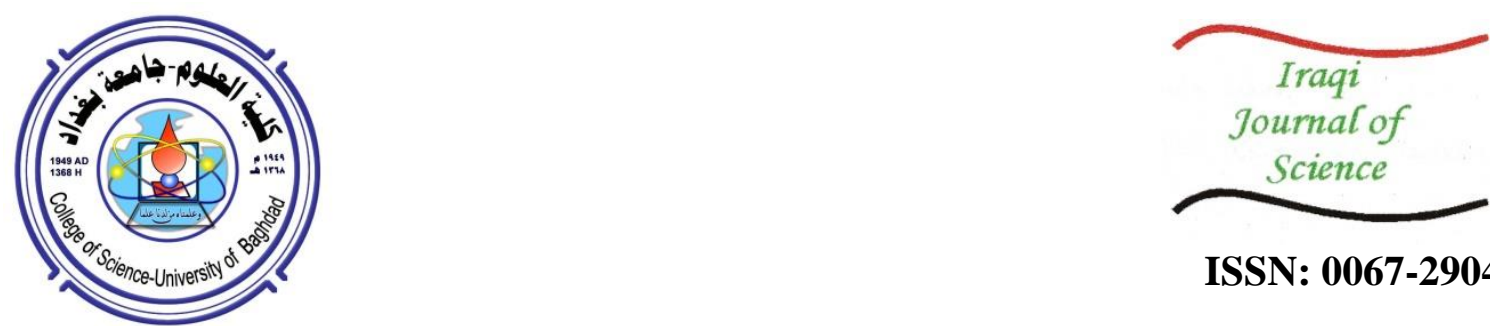

ISSN: 0067-2904

\title{
Bioherbicidal Potential of Eucalyptus and Clove Oil and their Combinations on Four Weedy Species
}

\author{
Ahmed Almarie \\ Field Crops Department, College of Agriculture, University of Anbar, Anbar, Iraq
}

\author{
Received: $15 / 9 / 2020$ \\ Accepted: 17/11/2020
}

\begin{abstract}
Essential oils of eucalyptus leaves and clove buds were isolated and tested for their bioherbicidal potential on different annual weed species. Gas ChromatographyMass Spectrophotometry analysis (GC-MS) identified thirteen compounds representing around $87.11 \%$ of the total isolated eucalyptus oil. The main constituent was 1,8-cineole, which accounted for $68.15 \%$ of the total identified compounds. As for clove oil, eleven compounds were identified, representing $90.03 \%$ of the total compounds. Eugenol was the dominant compound and accounted for $73.89 \%$. The bioherbicidal efficacy of the two oils and their combinations by three concentrations $(2.5,5$, and $10 \%)$ were tested on four weedy species, namely Chenopodium album, Raphanus raphanistrum, Melilotus indicus, and Sisymbrium irio. The isolated oils significantly affected the dry weight and inhibited the seedling growth of the four weedy species. Using the two essential oils, individually or within their combinations, showed the highest bioherbicidal efficacy against the targeted weeds in comparison with the synthetic herbicide. In addition, utilization of the two essential oils as natural bioherbicides caused an electrolyte leakage as a result of membrane disruption and loss of integrity of weed seedling tissues. The results showed the possibility of using eucalyptus and clove essential oils individually or in combination as a desirable alternative to synthetic herbicides for sustainable weed management.
\end{abstract}

Key words: Bioherbicidal potential, clove, Essential oil, Eucalyptus, weed plants

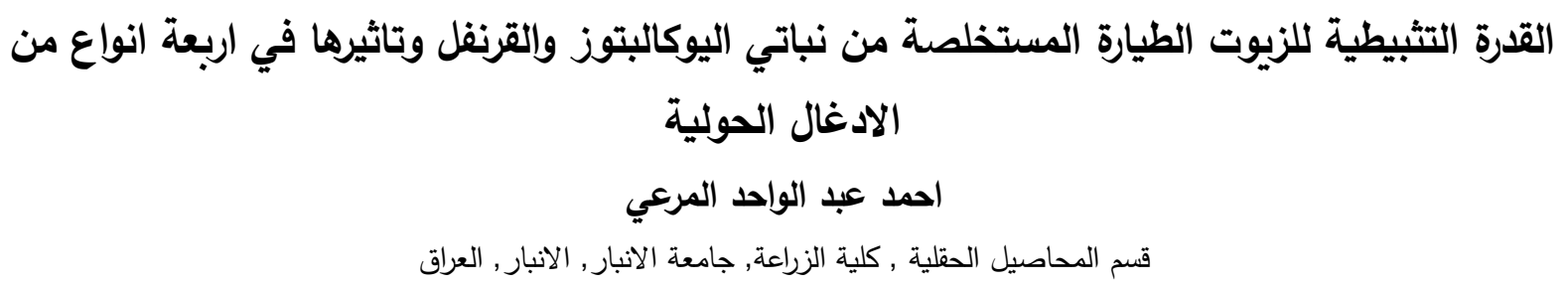

الخلاصة

استخلصت الزيوت الطيارة من نباتي اليوكالبتوز والقرنفل من اجل اختبار امقدرة التثبطية في نمو اربعة

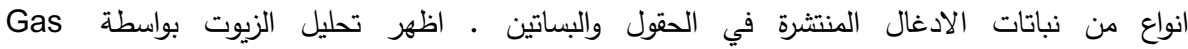

ان زيت اليوكالبتوز يتكون من ثلاثة

عشر مركبا كونت حوالي 87.11\% من مجموع مكونات الزيت وان المركب السينول كان الاكثر مكونا اذ

بلغت نسبته 68.15\% بينما تكون زيت القرنفل من احد عشر مركبا شكلت حوالي 90.03\% من اجمالي

Email: ag.ahmed.abdalwahed@uoanbar.edu.iq 


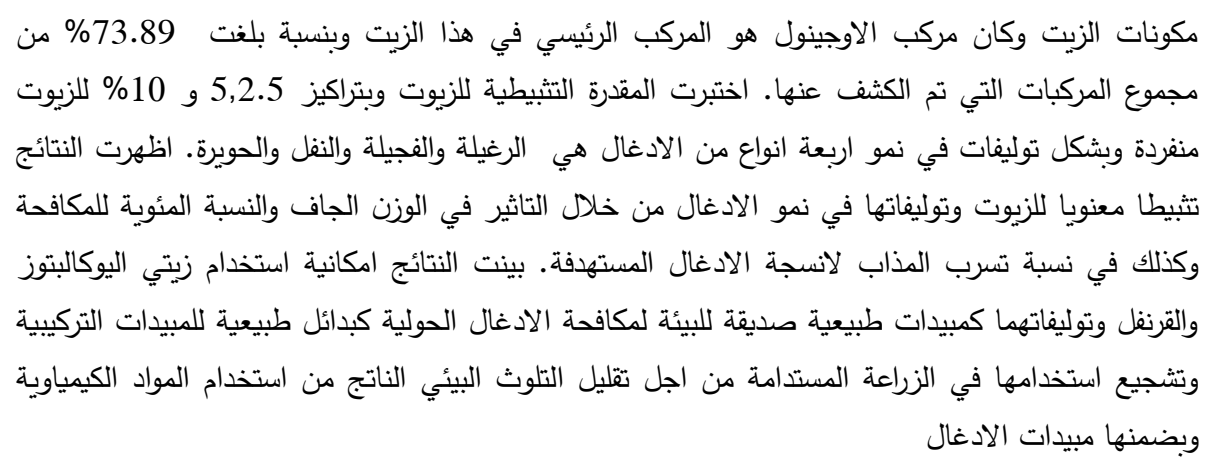

\section{Introduction}

The term of "weed" or "weeds" refers to unwanted plants that grow in undesirable places and cause negative impacts on agricultural production due to their competition with the economic crops on the basic growing requirements such as water and available nutrients. In fact, weed plants have the greatest negative impact when compared to the other pests in agricultural systems, such as diseases caused by insects [1]. Controlling the weeds through the use of the synthetic herbicides is considered as the most successful and efficient means that is widely used to control weeds. Moreover, the synthetic herbicides played a dominant role in the fight against the weeds and increase crop production qualitatively and quantitatively, as compared to other, including conventional, methods [2]. According to this dominance, the synthetic herbicides have become an integral part of the global agricultural production complex, as inputs required in a modern production system and accepted by farmers around the world as an integral part of the crop production [3]. Negative effects of these compounds on the environment and human health have raised awareness and created serious concerns [4].

The negative impacts of the synthetic herbicides continue even if they are applied at recommended rates. For example, the accumulation of glyphosate (s systemic nonselective synthetic herbicide) was found in groundwater and sources of fresh drinking water as a result of leaching by irrigation water and rainfall. Therefore, it could be one of many reasons, which are responsible to decrease microorganisms and biomass activities, including those of plants, fish, and birds. In addition, the continuous use of synthetic herbicides leads to another problem known as weed resistance $[5,6]$. Weed resistance means non-relevancy of synthetic herbicide on the same weed type as a result of using the same active ingredient continuously, which causes an increasing weed population by producing new generations. Weed resistance leads to the usage of herbicides that are more lethal and thereby increasing the damage to the environment and organisms around the spraying area $[7,8]$. Therefore, finding other solutions to control weed and avoid the negative impacts posed by synthetic herbicides has become very necessary. Allelopathy comes at the forefront of possible solutions to provide natural solutions that are less harmful to the environment than the synthetic herbicides. They are used as defence mechanisms in some plants when exposed to external potential threat from the surrounding environment, including nearby plants. This defence mechanism is known as allelopathy [9]. Plant secondary metabolites which are responsible for showing allelopathy actions are known as allelochemicals. Allelochemical compounds are manufactured through the shikimate or isoprenoid pathway and used by plants as well as various organisms such as bacteria and fungi to synthesize allelochemicals. Essential oils are considered as one of the examples of the secondary plant products that typically contain different compounds of allelochemicals, consisting mainly of terpenoids and phenolics.

Essential oils have become today as an attractive alternative to synthetic pesticides in programs of integrated pest management, including antibacterial, fungal, and antimicrobial programs. Moreover, there are no adverse threats from the use of these natural products, such as the volatile oils that rely on allelochemical materials, on the environment and human health [7, 10, 11, 12]. Previous studies indicated that the essential oils have shown good efficacy as natural bioherbicides against weed, by preventing germination and inhibiting growth [13]. Therefore, the current research aims to examine the bioherbicidal ability of eucalyptus and clove oil, and their combinations, on the growth development of four weed species and their possible use as natural weed killers. 


\section{Materials and Methods \\ Isolation and analysis of essential oils}

Fresh and healthy eucalyptus leaves (Eucalyptus globulus) were collected from the eucalyptus trees growing in the College of Agriculture, University Of Anbar, Anbar province, Iraq, and dried under laboratory conditions. In addition, buds of clove plant (Syzygium aromaticum) were purchased from the local market. Leaves and buds were chopped and isolated by hydro distillation method using a Clevenger apparatus. An amount of 250 grams (leaves or buds) was used for each distillation process. After the completion of the process of distillation, the final yield of the isolated oils was stored in Umber glass tubes and kept in the refrigerator until use. The percentage of the final product of each isolated oil was calculated as an average of five samples.

Eucalyptus and clove essential oil samples were analyzed in the laboratory of bioprocess engineeringSchool of biosystems engineering - UniMAP - Malaysia, using a Shimadzu Gas Chromatography apparatus with Elite-5MS non-polar fused silica capillary column $(30 \mathrm{~m} \times 0.25 \mathrm{~mm}$ ID, film thickness of $0.25 \mathrm{~mm}$ ). The oven temperature was increased from $40{ }^{\circ} \mathrm{C}$ to $250{ }^{\circ} \mathrm{C}$ at a rate of $10{ }^{\circ} \mathrm{C} / \mathrm{min}$; Injector temperature, $250{ }^{\circ} \mathrm{C}$; injection volume, $0.5 \mu \mathrm{L}$; transfer temperature, $250{ }^{\circ} \mathrm{C}$. The carrier gas used was helium; at a flow rate of $1.0 \mathrm{ml} / \mathrm{min}$. Mass spectra were taken over an $\mathrm{m} / \mathrm{z}$ of $40-600$ and interface line temperature of $250{ }^{\circ} \mathrm{C}$. The constituents of essential oils were identified based on their Kovats Index, calculated in relation to the retention time of a series of alkanes $(\mathrm{C} 4-\mathrm{C} 28)$ as reference products compared with the chemical compounds gathered by Adams table [14]. The mass spectra of chemical compounds were gathered from the NIST-MS and Wily Library.

\section{Weed seed collection}

Mature seeds of four annual weed types belonging to three plant families widespread in crop fields, namely Goosefoot Chenopodium album, Wild Radish Raphanus raphanistrum, Sweet clover Melilotus indicus, and London rocket Sisymbrium irio, were collected from mature weed plants found in the College of Agriculture fields during the 2019 season. Seeds were diagnosed and conserved until the date of the experiment.

\section{Formulation of bioherbicides}

Bioherbicides were formulated (eucalyptus, clove oils, and their combinations) as active ingredients with different concentrations $(2.5,5$ and $10 \%)$ of the spray solution using distilled water. Soy lecithin and Sodium Dodycal Sulphate (S.D.L) were added in $0.5 \%$ as surfactant agents. The final spray solutions were placed in a magnetic stirrer for 30 minutes for homogeneity [15]. The synthetic herbicide was Epostar SL, which is a common contact herbicide containing glyphosate $48 \%$ as an active ingredient and used at the recommended dose $\left(10 \mathrm{~L} / \mathrm{ha}^{-1}\right)$.

\section{Bioherbicidal potential of essential oils}

Seeds of the four weed species were cultivated in $30 \mathrm{~cm}$ diameter plastic pots filled with fine sand. Weed seeds were bedded in $1-2 \mathrm{~cm}$ depth and watered until reaching 4-6 true leaf stage. Then, seedlings of the four weed types were sprayed with different constrictions of bioherbicides of eucalyptus and clove oils and their combinations. Control pots were served by distilled water. At two weeks after treatment, dry weight $(\mathrm{g})$ was measured by taking the average of the five seedlings from each treatment. The weed control percentage was measured using the expression described by [1], with the formula: Weed control $(\%)=((\mathrm{A}-\mathrm{B}) / \mathrm{A}) \times 100$, wherein $\mathrm{A}$ is weed density of treated treatment, and B is weed density of untreated treatment (controls). Relative electrolyte leakage (\%) of the weed seedling tissues was calculated as previously described [15], by taking five leaf discs from each treatment $(0.5 \mathrm{~cm}$ diameter) and floating them in $5 \mathrm{ml}$ distilled water for 30 minutes. The conductivity of the medium was measured (C1). Then, a test tube containing the leaf tissue was boiled for 15 minutes and conductivity was measured (C2). The relative electrolyte leakage (\% REL) was calculated as: $\mathrm{REL} \%=(\mathrm{C} 1 / \mathrm{C} 2) \times 100$.

\section{Results and Discussion}

\section{Chemical composition of the essential oils}

The total yield, chemical composition, and the percentage content of the individual components of the hydrodistillated eucalyptus and clove essential oils are summarized in table (1). The eucalyptus essential oil yielded $0.95 \%$, while clove oil yielded $14.65 \%$, as a final isolated yield. The number of total identified compounds of the eucalyptus essential oil recorded in the current study was more than 
13 compounds, comprising around $87.11 \% \pm 1.19$ of the total identified compounds. 1,8-cineole was the dominant compound in the eucalyptus oil, accounting $68.15 \% \pm 0.96$ followed by $\alpha$-Terpineol $7.37 \% \pm 0.39$, limonene $3.07 \% \pm 0.21$, and pinocarveol $2.70 \% \pm 0.23$. The other identified compounds did not reach the limit of $2.5 \%$. The current results are in agreement with those previously published [16], which reported that 1,8-cineole was the major compound in eucalyptus oil, comprising 49.07 to $83.59 \%$ in all the seven species of eucalyptus tree isolated. The findings of the present study are also in agreement with the findings of an earlier work [17] which demonstrated that 1,8-cineole was the major compound in the essential oil isolated from E. globulus (55.29\%).

As for the clove oil, the number of the identified compounds was 11 individual compounds, comprising $90.93 \%$ of the total identified compounds. Eugenol was the major compound that represented $73.89 \%$ of the total compounds, followed by $\beta$-caryophyllene, which comprised $4.01 \%$. The findings of the present study are supported by the findings of previous studies which highlighted that the eugenol compound was the main compound in clove essential oil isolated from clove buds, with a percentage that ranged from 67 to $95 \%[18,19]$.

Table 1- Chemical composition of eucalyptus and clove essential oils

\begin{tabular}{|c|c|c|c|c|c|}
\hline \multicolumn{3}{|c|}{ Eucalyptus } & \multicolumn{3}{|c|}{ Clove } \\
\hline \multicolumn{2}{|r|}{ Compound } & \multirow{2}{*}{$\begin{array}{c}\text { Area \% } \\
68.15 \pm 0.96\end{array}$} & \multicolumn{2}{|r|}{ Compound } & \multirow{2}{*}{$\begin{array}{c}\text { Area \% } \\
73.89 \pm 1.28\end{array}$} \\
\hline 1 & 1,8-cineole & & 1 & Eugenol & \\
\hline 2 & $\alpha$-Terpineol & $7.37 \pm 0.39$ & 2 & $\beta$-Caryophyllene & $4.01 \pm 0.28$ \\
\hline 3 & Limonene & $3.07 \pm 0.21$ & 3 & Thymol & $1.92 \pm 0.49$ \\
\hline 4 & Pinocarveol & $2.70 \pm 0.23$ & 4 & $\alpha$-humulene & $0.78 \pm 0.19$ \\
\hline 5 & Terpinene-4-ol & $2.24 \pm 0.19$ & 5 & Guaiol & $0.64 \pm 0.31$ \\
\hline 6 & $\beta$-Eudesmol & $1.39 \pm 0.11$ & 6 & P-Cymene & $0.48 \pm 0.17$ \\
\hline 7 & P-Cymene & $1.35 \pm 0.14$ & 7 & Linalool & $0.43 \pm 0.11$ \\
\hline 8 & $\alpha$-pinene & $1.26 \pm 0.28$ & 8 & Eugenol acetate & $0.41 \pm 0.39$ \\
\hline 9 & Guaiene & $1.13 \pm 0.12$ & 9 & Eucalptol & $0.32 \pm 0.09$ \\
\hline 10 & $\alpha$ - caryophyllene & $0.57 \pm 0.09$ & 10 & Myrcene & $0.27 \pm 0.10$ \\
\hline 11 & Linalool & $0.63 \pm 0.08$ & 11 & Other components & $15.65 \pm 2.02$ \\
\hline 12 & Carvacrol & $0.60 \pm 0.10$ & \multirow{3}{*}{\multicolumn{2}{|c|}{ Total identified components }} & \multirow{3}{*}{$90.39 \% \pm 1.1 \mathrm{C}$} \\
\hline 13 & Other components & $9.38 \pm 0.29$ & & & \\
\hline \multicolumn{2}{|c|}{ Total identified components } & $87.11 \% \pm 1.19$ & & & \\
\hline
\end{tabular}

\section{Bioherbicidal bioassay \\ Weed seedling dry weight $(\mathrm{g})$}

The bioherbicidal potential of eucalyptus and clove oil, and their combinations, on the four weed seedling's dry matter weight, after being applied at the three concentrations $(2.5,5$, and $10 \%)$ under the greenhouse condition, are summarized in Table 2. Most of the essential oil treatments showed a 
decrease in the dry matter weight when treated with the three different concentrations; they differed significantly from the controls. The application of the essential oils at the lowest and the medium concentrations ( 2.5 and 5\%), and even their combinations, failed to reach the same significant level of influence of the synthetic herbicide. In the case of the highest concentration (10\%), considerable inhibition in the dry matter weight of the four targeted weed species was observed. The inhibition approached the same significant level of inhibition reached by the synthetic herbicide. The current results are supported by those of previous studies [20,21], which found significant phytotoxic effects of essential oils used at different doses on seedling's dry matter weight in various weed species. Using 1,8-cineole as a post-emergence herbicide showed good efficacy against annual ryegrass and radish, which depended on 1,8-cineole content in eucalyptus oil [22]. Regarding eugenol, the major component of clove oil, it was found to cause retardation of seed germination and suppression of seedling growth of various weed species, by causing a reduction in chlorophyll content and respiratory activity [23].

Table 2- Bioherbicidal effects of eucalyptus and clove essential oil on dry matter $(\mathrm{g})$ of the four weed species.

\begin{tabular}{|c|c|c|c|c|c|}
\hline \multirow{2}{*}{ Concentration \% } & \multirow{2}{*}{ Essential oil } & \multicolumn{4}{|c|}{ Weed species } \\
\hline & & Ch. album & $\begin{array}{l}R . \\
\text { raphanistrum }\end{array}$ & $\begin{array}{l}\text { M. } \\
\text { indicus }\end{array}$ & S. irio \\
\hline \multirow{3}{*}{$10 \%$} & Eucalyptus & $71.26 \mathrm{ab}$ & $52.50 \mathrm{ab}$ & $64.22 \mathrm{~b}$ & $32.61 \mathrm{ab}$ \\
\hline & Clove & $58.11 \mathrm{a}$ & $62.00 \mathrm{bc}$ & $79.77 \mathrm{~b}$ & $40.42 b c$ \\
\hline & Clove + Eucalyptus & $39.67 \mathrm{a}$ & $65.04 \mathrm{bc}$ & $56.45 \mathrm{ab}$ & $34.14 \mathrm{ab}$ \\
\hline \multirow{3}{*}{$5 \%$} & Eucalyptus & $91.00 \mathrm{bc}$ & $75.67 \mathrm{~cd}$ & $80.89 \mathrm{~b}$ & $57.97 \mathrm{~d}$ \\
\hline & Clove & $81.53 \mathrm{bc}$ & $68.6 \mathrm{bcd}$ & $71.81 \mathrm{~b}$ & $42.28 b c$ \\
\hline & Clove + Eucalyptus & $94.89 \mathrm{bc}$ & $78.38 \mathrm{~cd}$ & $47.30 \mathrm{a}$ & $50.93 \mathrm{~cd}$ \\
\hline \multirow{3}{*}{2.5} & Eucalyptus & $86.29 \mathrm{bc}$ & $82.10 \mathrm{~cd}$ & $71.50 \mathrm{~b}$ & $57.61 \mathrm{~d}$ \\
\hline & Clove & $95.56 \mathrm{c}$ & $82.30 \mathrm{~cd}$ & $73.37 \mathrm{~b}$ & $53.92 \mathrm{~cd}$ \\
\hline & Clove + Eucalyptus & $61.66 \mathrm{a}$ & $89.18 \mathrm{~d}$ & $83.21 \mathrm{~b}$ & $49.18 \mathrm{~cd}$ \\
\hline \multicolumn{2}{|l|}{ Weedy check } & $142.30 \mathrm{~d}$ & $82.97 \mathrm{~cd}$ & $83.41 \mathrm{~b}$ & $57.47 \mathrm{~d}$ \\
\hline \multicolumn{2}{|l|}{ Epostar SL } & $44.43 \mathrm{a}$ & $35.55 \mathrm{a}$ & $45.44 \mathrm{a}$ & $24.89 a$ \\
\hline
\end{tabular}

\section{Weed control percentage (percentage)}

As for weed control percentage, the data presented in Table (3) show the variation in the weed control of the four weed species at the three concentrations of eucalyptus and clove oil and their combinations $(2.5,5$, and $10 \%)$, with the level of significance being established at $p \leq 0.05$. All the formulation of the two essential oils and their combinations achieved a significant bioherbicidal efficacy in terms of controlling the four weed species, in comparison with the controls. Weed control was increased gradually by increasing the concentration of essential oils in the spray solution. The data presented in Table 3 show that the two essential oils at the medium and highest concentrations 
succeeded to reach the same significant level of the inhibition of the synthetic herbicide. The findings of the present study are incoherent with the findings of previous studies $[8,24]$, which found that the highest dose was the most effective as compared with the other doses against a wide range of weeds. However, the optimum dose of essential oils depends on several factors, mainly the type of isolated oil and its allelochemical contents, the type and growth stage of the targeted weed, and the growing conditions [25].

Table 3- Bioherbicidal effects of eucalyptus and clove essential oil on weed control (\%) of the four weed species

\begin{tabular}{|c|c|c|c|c|c|}
\hline \multirow{2}{*}{ Concentration \% } & \multirow{2}{*}{ Essential oil } & \multicolumn{4}{|c|}{ Weed species } \\
\hline & & Ch. album & $\begin{array}{c}R . \\
\text { raphanistrum }\end{array}$ & $\begin{array}{c}M . \\
\text { indicus }\end{array}$ & S. irio \\
\hline \multirow{3}{*}{$10 \%$} & Eucalyptus & $62.74 \mathrm{a}$ & $62.58 \mathrm{ab}$ & $63.35 \mathrm{a}$ & $58.96 \mathrm{ab}$ \\
\hline & Clove & 49.36ab & $57.69 \mathrm{ab}$ & $56.86 \mathrm{ab}$ & $51.22 \mathrm{abc}$ \\
\hline & $\begin{array}{c}\text { Clove }+ \\
\text { Eucalyptus }\end{array}$ & $51.40 \mathrm{ab}$ & $59.43 \mathrm{ab}$ & $54.12 \mathrm{ab}$ & $50.80 \mathrm{abc}$ \\
\hline \multirow{3}{*}{$5 \%$} & Eucalyptus & $49.01 \mathrm{ab}$ & $46.40 \mathrm{bcd}$ & $54.10 \mathrm{ab}$ & $47.48 \mathrm{abc}$ \\
\hline & Clove & $46.33 \mathrm{ab}$ & $47.67 \mathrm{bcd}$ & $47.00 \mathrm{~b}$ & $44.07 \mathrm{c}$ \\
\hline & $\begin{array}{c}\text { Clove }+ \\
\text { Eucalyptus }\end{array}$ & $47.38 \mathrm{ab}$ & $50.38 \mathrm{abc}$ & $48.89 \mathrm{~b}$ & $45.83 \mathrm{bc}$ \\
\hline \multirow{3}{*}{2.5} & Eucalyptus & $30.84 \mathrm{c}$ & $34.50 \mathrm{~cd}$ & $32.67 \mathrm{c}$ & $30.63 \mathrm{~d}$ \\
\hline & Clove & $26.98 \mathrm{c}$ & $36.98 \mathrm{~cd}$ & $31.98 \mathrm{c}$ & $29.98 \mathrm{~d}$ \\
\hline & $\begin{array}{c}\text { Clove }+ \\
\text { Eucalyptus }\end{array}$ & $20.83 \mathrm{c}$ & $30.83 \mathrm{~cd}$ & $25.83 \mathrm{c}$ & $24.28 \mathrm{~d}$ \\
\hline \multicolumn{2}{|c|}{ Weedy check } & Od & $0 \mathrm{e}$ & Od & $0 \mathrm{e}$ \\
\hline \multicolumn{2}{|c|}{ Epostar SL } & $63.05 \mathrm{a}$ & $66.5 \mathrm{a}$ & $65.00 \mathrm{a}$ & $60.94 a$ \\
\hline
\end{tabular}

\section{Relative electrolyte leakage}

Figure (1) shows the changes in the relative electrolyte leakage values of the four-targeted weed seedlin tissues affected by the application of the oils isolated from eucalyptus and clove oils, and their combinations, with three different concentrations. In general, the activity of the two essential oils was more pronounced and caused acute electrolyte leakage in all the four targeted weeds when the concentration of the essential oil was increased from $2.5 \%$ (the lowest) to $10 \%$ (the highest). The results of the current study are in agreement with the latest studies conducted in this field $[15,26]$ which reported that the application of the essential oils inhibited plant growth through membrane disruption. 


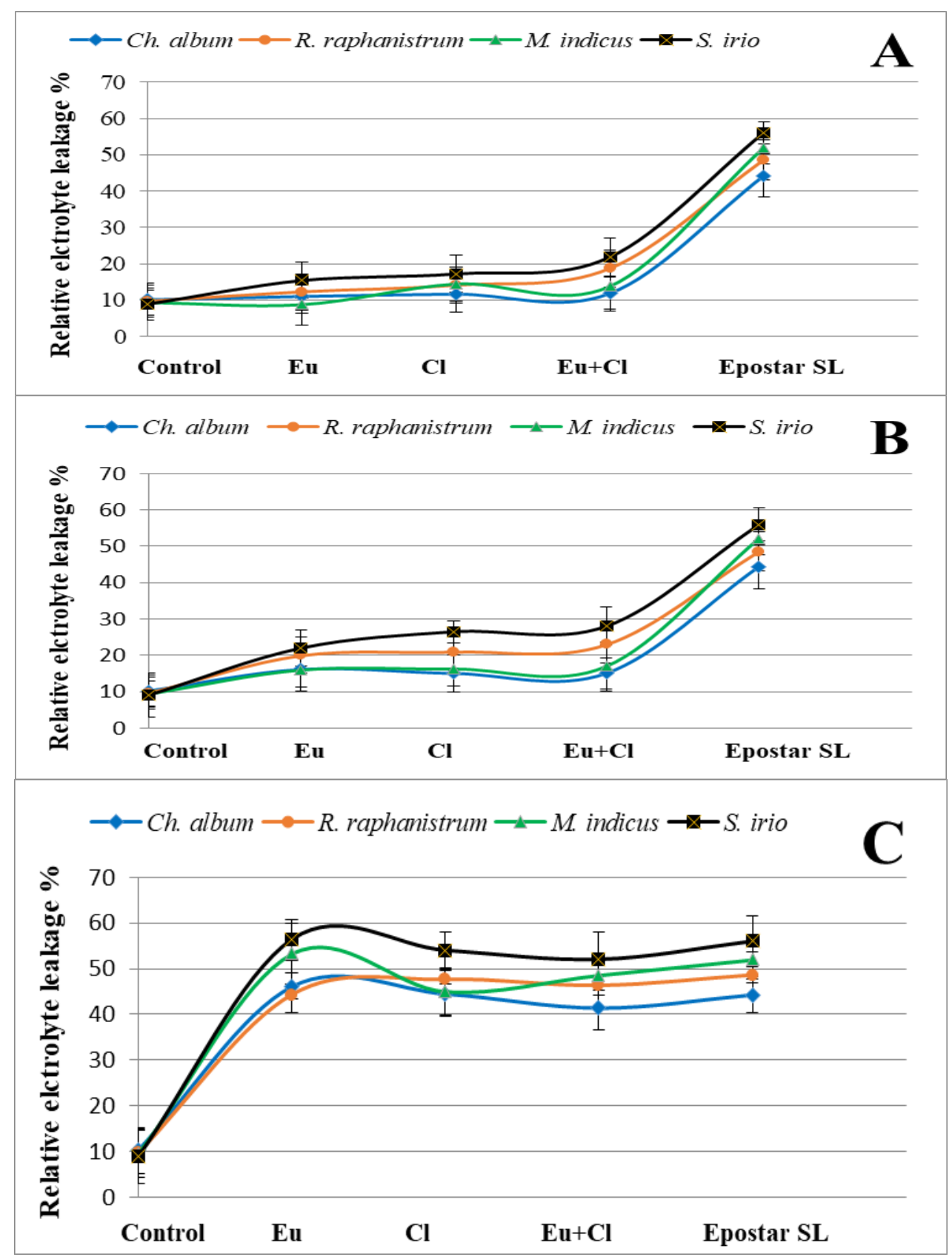

Figure1- Relative electrolyte leakage of four recipient test weeds affected by eucalyptus and clove oils and their combinations in various concentrations (A: 2.5\%, B: 5\%, and C:10\%) compared with controls.

Membrane disruption can be considered as one of the underlying mechanisms of plants' phytotoxic effects, which results in cell death and growth inhibition. An earlier study [27] reported that secondary metabolites in essential oils, such as phenolics and terpenoids, are less specific and attack a multitude of proteins of the cell membrane by building hydrogen, hydrophobic, and ionic bonds. As a result, they destroy the bioactivities of these proteins. 


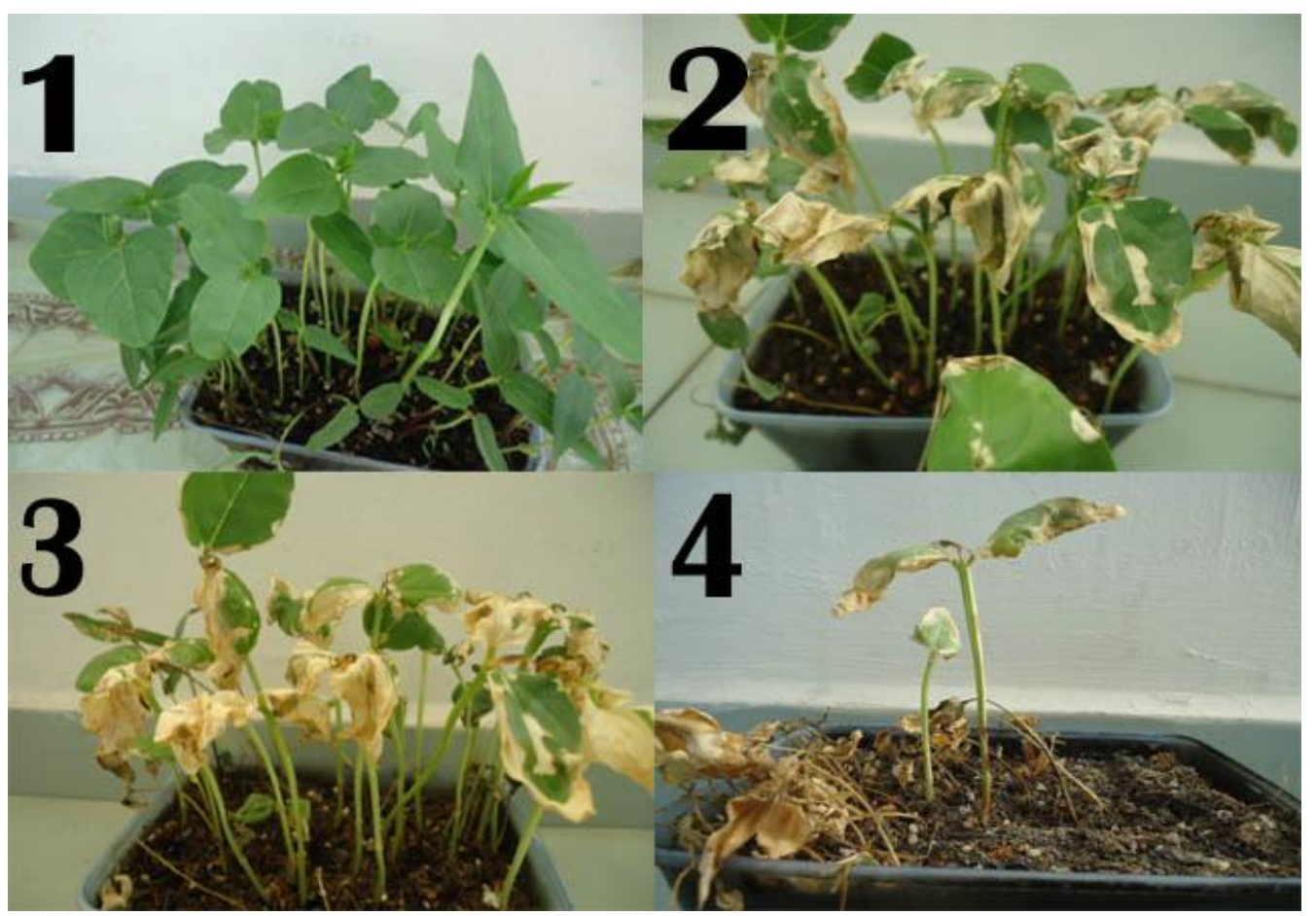

Figure 2- Bioherbicidal potential of eucalyptus and clove oils with a combination ratio of $10 \%$ on $C h$. Album weed seedling; Mode of Action simulation.

\section{Conclusions}

In the present study, eucalyptus and clove oil showed a strong bioherbicidal potential against different species of annual weeds growing in the Iraqi environments. These results indicate that these oils could be useful for developing natural weed killers. Furthermore, studies are required to evaluate the bioherbicidal potential of these essential oils as post-emergence bioherbicides under field conditions and determine their effects on non-target weed species.

\section{References}

1. Zimdahl, R. L. 2013. Fundamentals of weed science: Academic Press. http:// base. dnsgb. com.ua/files/ book/ Agriculture/Weed/Fundamentals-of-Weed-Science.pdf.

2. Gianessi, L., and Williams, A. 2012. The importance of herbicides for natural resources conservation in the USA. 10.1007/978-3-642-55262-5_14. https://croplifefoundation. files.wordpress.com/2012/05/springer-chapter.pdf

3. Gianessi, L. P. 2013. The increasing importance of herbicides in worldwide crop production. Pest management sci., 69(10), 1099-1105.

4. Saha, S., Dutta, D., Karmakar, R., and Ray, D. P. 2012. Structure-toxicity relationship of chloroacetanilide herbicides: relative impact on soil microorganisms. Environmental Toxicology and pharmacology, 34(2), 307-314.

5. Ratcliff, A. W., Busse, M. D., \& Shestak, C. J. 2006. Changes in microbial community structure following herbicide (glyphosate) additions to forest soils. Applied Soil Ecology, 34(2), 114-124.

6. Vencill, W. K., Nichols, R. L., Webster, T. M., Soteres, J. K., Mallory-Smith, C., Burgos, N. R., \& McClelland, M. R. 2012. Herbicide resistance: toward an understanding of resistance development and the impact of herbicide-resistant crops. Weed Science, 60 (SP1), 2-30.

7. Heap, I. 2014. Herbicide resistant weeds Integrated Pest Management (pp. 281-301): Springer.

8. Ismail, A., Lamia, H., Mohsen, H., Samia, G., \& Bassem, J. 2013. Chemical composition, bioherbicidal and antifungal activities of essential oils isolated from Tunisian common cypress (Cupressus sempervirens L.). Journal of Medicinal Plants Research,7(16), 1070-1080.

9. Soltys, D., Krasuska, U., Bogatek, R., and Gniazdowska, A. 2013. Allelochemicals as bioherbicides - present and perspectives. Herbicides - current research and case studies in use, Intech open, 517-542. 
10. Koul, O., Walia, S., and Dhaliwal, G. 2008. Essential oils as green pesticides: potential and constraints. Biopesticides international, 4(1), 63-84.

11. Salman, A. D., Amer, Z., \& Abud_Rahman, E. S. 2017. Bacteriological Study of Pseudomonas Aeruginosa Isolated from Different Infections and Study Antimicrobial Activities of Plant Extract Solanum Nigrum Against It. Iraqi journal of Science, 58(4c), 2278-2284.

12. Ali, L. F., \& Hussein, N. S. M. 2018. The Biological Activity of Eucalyptus rostrata Leaves Extraction against E. coli and Staphylococcus aureus isolated from Iraqi Patients. Iraqi Journal of Science, 59(4A), 1806-1810.

13. Barbosa, L. C. A., Filomeno, C. A., \& Teixeira, R. R. 2016. Chemical variability and biological activities of Eucalyptus spp. essential oils. Molecules, 21(12), 1671.

14. Adams, R. P. (2007). Identification of essential oil components by gas chromatography/mass spectrometry (Vol. 456). Carol Stream, IL: Allured publishing corporation.

15. Almarie, A. A., Mamat, A. S., Wahab, Z., and Rukunudin, I. H. 2016. Chemical composition and phytotoxicity of essential oils isolated from Malaysian plants. Allelopathy Journal, 37(1), 55-69.

16. Sebei, K., Sakouhi, F., Herchi, W., Khouja, M. L., and Boukhchina, S. 2015. Chemical composition and antibacterial activities of seven Eucalyptus species essential oils leaves. Biological research., 48(1), 1-5.

17. Harkat-Madouri, L., Asma, B., Madani, K., Said, Z. B. O. S., Rigou, P., Grenier, D., and Boulekbache-Makhlouf, L. 2015. Chemical composition, antibacterial and antioxidant activities of essential oil of Eucalyptus globulus from Algeria. Industrial Crops and Products., 78, 148-153.

18. Yang, Y. C., Wei, M. C., and Hong, S. J. 2014. Ultrasound-assisted extraction and quantitation of oils from Syzygium aromaticum flower bud (clove) with supercritical carbon dioxide. Journal of Chromatography A, 1323, 18-27.

19. Khalil, A. A., ur Rahman, U., Khan, M. R., Sahar, A., Mehmood, T., and Khan, M. 2017. Essential oil eugenol: sources, extraction techniques and nutraceutical perspectives. RSC advances, 7(52), 32669-32681.

20. Agnieszka, S., Magdalena, R., Jan, B., Katarzyna, W., Malgorzata, B., Krzysztof, H., and Danuta, K. 2016. Phytotoxic Effect of Fiber Hemp Essential Oil on Germination of Some Weeds and Crops. Journal of Essential Oil Bearing Plants, 19(2), 262-276.

21. De Oliveira, C. M., das Graças Cardoso, M., da Silva Figueiredo, A. C., de Carvalho, M. L. M., de Miranda, C. A. S. F., Albuquerque, L. R. M., and de Andrade Santiago, J. 2014. Chemical Composition and Allelopathic Activity of the Essential Oil from Callistemon viminalis (Myrtaceae) Blossoms on Lettuce (Lactuca sativa L.) Seedlings. American Journal of Plant Sciences, 5(24), 3551.

22. Barton, A.F., Clarke, B.R., Dell, B., and Knight, A.R. 2014. Post-emergent herbicidal activity of cineole derivatives. Journal of Pest Sciences., 87, 531-541.

23. Ahuja, N., Batish, D. R., Singh, H. P., and Kohli, R. K. 2015. Herbicidal activity of eugenol towards some grassy and broad- leaved weeds. Journal of Pest Sciences, 88(1), 209-218.

24. Amri, I., Hanana, M., Jamoussi, B., and Hamrouni, L. 2017. Essential oils of Pinus nigra JF Arnold subsp. laricio Maire: Chemical composition and study of their herbicidal potential. Arab. Journal of Chemistry.,10, S3877-S3882.

25. Dubey, N. K. 2010. Natural products in plant pest management: CABI. http:// www. cabi. org/bookshop/book/9781845936716.

26. Kumrungsee, N., Pluempanupat, W., Koul, O., \& Bullangpoti, V. 2014. Toxicity of essential oil compounds against diamondback moth, Plutella xylostella, and their impact on detoxification enzyme activities. Journal of Pest Science, 87(4), 721-729.

27. Wink, M. 2015. Modes of action of herbal medicines and plant secondary metabolites. Medicines, 2(3), 251-286. 